\title{
LONG-TERM SHORELINE CHANGES ON MARGINAL COAST OF TIDAL FLAT IN TOKYO BAY AND RAPID DEFORMATION OF SAND BARS OWING TO TSUNAMI
}

\author{
Yasumitsu Mikami ${ }^{1}$, Akio Kobayashi ${ }^{1}$, Takaaki Uda ${ }^{2}$ and Yasuhito Noshi ${ }^{1}$
}

\begin{abstract}
Long-term shoreline changes on the marginal coast of the Banzu tidal flat in Tokyo Bay were investigated using aerial photographs. In the area immediately north of the Obitsu River mouth, the beach was eroded owing to the decrease in sand supply from the river, resulting in the exposure of a layer composed of cohesive material in the previous tidal flat, and sand was transported northward to form a sand spit at the mouth of the north tributary. In 2011, the giant tsunami generated by the Great East Japan Earthquake propagated deep into Tokyo Bay, and sand bars were pushed landward by $7 \mathrm{~m}$ parallel to the shoreline owing to the tsunami overflow.
\end{abstract}

Keywords: Tokyo Bay; Banzu tidal flat; shoreline changes; aerial photographs; 2011 tsunami; longshore sand transport

\section{INTRODUCTION}

Vast tidal flats used to extend offshore of the eastern coasts in Tokyo Bay, but most of them disappeared following large-scale land reclamation in the era of high economic growth starting in the 1960s. However, a tidal flat with an area of 1,400 ha, one of the largest in Japan, was left around the Obitsu River mouth (Murakami 2008). Many ecological studies have been carried out because this tidal flat is an important spawning ground for fish and a field for the growth of rare plant species. Since the wave action on these coasts is much weaker than that on exposed coasts, tidal flats can develop, and many studies have focused on sand transport caused by tidal currents. A sandy beach, however, can be formed on marginal coasts under waves, whereas a sand spit or a barrier island is formed on tidal flats owing to their shallowness, even though the scale of the topographic changes is small. Few studies, however, have been carried out on beach changes on the marginal coasts of tidal flats. We therefore investigated the long-term shoreline changes on these coasts using past aerial photographs, selecting the Banzu tidal flat, as shown in Fig. 1, as a study area. In particular, the giant tsunami generated by the Great East Japan Earthquake in 2011 propagated deep into Tokyo Bay, and the marginal coasts of this tidal flat were affected by this tsunami, causing the inundation of beach ridges and the deformation of sand bars. The second aim of this study was to study the impact of this tsunami on the beach in this area.

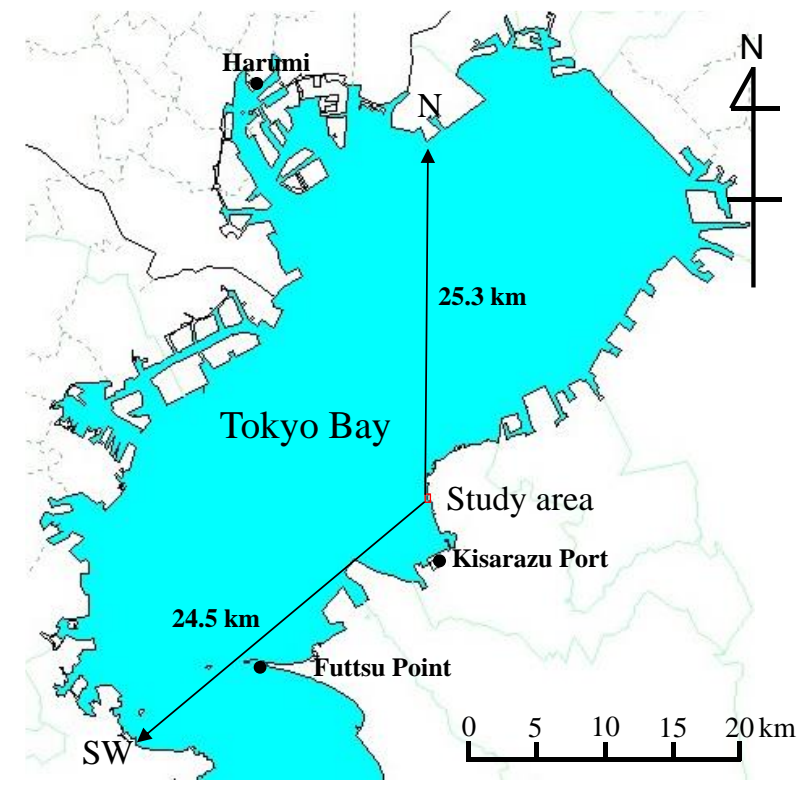

Figure 1. Location of study area in Tokyo Bay.

\footnotetext{
${ }^{1}$ Nihon University, 7-24-1 Narashinodai, Funabashi, Chiba 274-8501, Japan

2 Head, Shore Protection Research, Public Works Research Center, 1-6-4 Taito, Taito, Tokyo 110-0016, Japan
} 


\section{METHOD OF INVESTIGATION}

To investigate the beach changes on the marginal coasts of the Banzu tidal flat, aerial photographs were collected and the shoreline changes were examined using these photographs. The rectangular area in Fig. 2 is the study area, which is subdivided into subareas 1 and 2. Field observation was carried out in these subareas on April 19, 2014 and April 17, 2016. Transects a, b, and c were set between the Obitsu River and the north tributary, as shown in Fig. 2, together with transects d, e, and f north of the tributary, and the longitudinal profiles along these transects were measured on November 5 and 6, 2014. Simultaneously, vertical holes were excavated at several points along each transect, and the elevation above mean sea level (MSL) of the boundary between the sand and the mud layers composed of cohesive material was measured.

The wave rose at Kisarazu observatory was used as a reference, because the study area is located in the middle of Tokyo Bay, as shown in Fig. 1, and wind waves are predominant. Referring to the results of the meteorological observation between 2000 and 2012, Fig. 3 shows the mean wind rose in the entire period. The maximum probability of the wind direction is $21.2 \%$ in the SSW direction, followed by $17.4 \%$ in the $\mathrm{N}$ direction. The shoreline of the marginal coasts of the Banzu tidal flat extends in the S-N direction with some irregularities, as shown in Fig. 2, and thus the easterly wind can be neglected when considering the development of wind waves incident to the Banzu tidal flat, and the predominant wind directions become SSW and N. Of the two directions, the wind fetch in the N direction is $25.3 \mathrm{~km}$, as shown in Fig. 1. On the other hand, because the wind fetch to SSW is truncated by reclaimed land, the wind fetch to SW is calculated instead of that to SSW. The resulting wind fetch to SW is $24.5 \mathrm{~km}$. Moreover, a large area of reclaimed land is located $1.1 \mathrm{~km}$ north of the Obitsu River mouth, as shown in Fig. 2, protruding $60 \mathrm{~m}$ into the bay relative to the west boundary of the coast, and northerly waves can be sheltered by this reclaimed land. Regarding the tide level at Kisarazu Port, the high and low water levels (HWL and LWL) at the Banzu tidal flat are +0.5 and $-0.5 \mathrm{~m}$ above MSL, respectively.

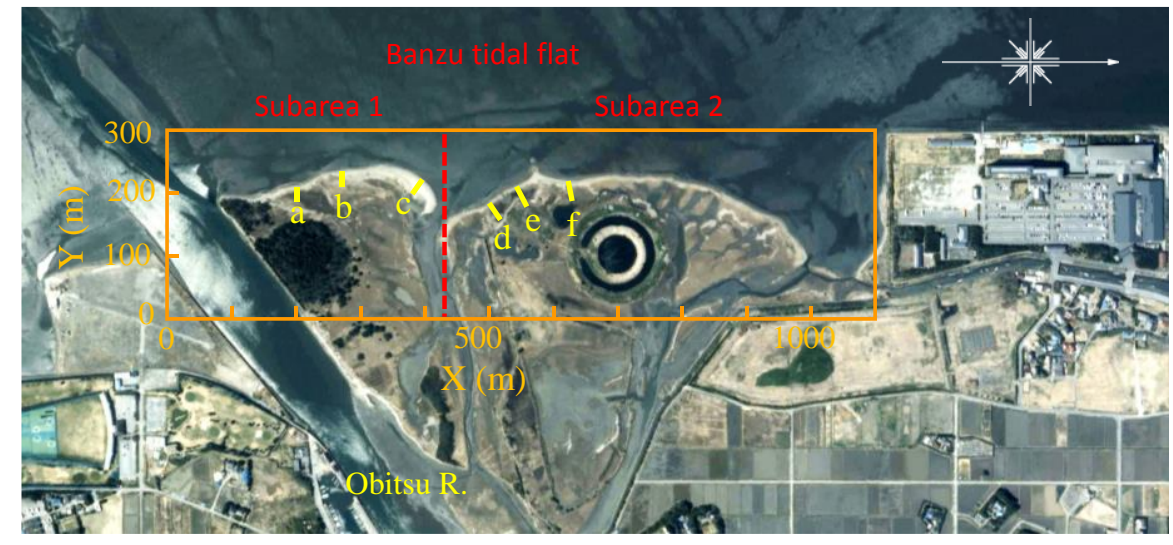

Figure 2. Location of study area in Banzu tidal flat, coordinate system, and location of transects a-f.

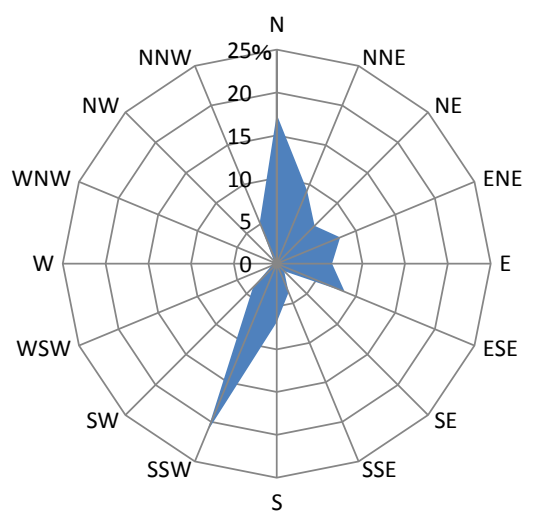

Figure 3. Wind rose at Kisarazu Port. 


\section{BEACH CHANGES IN SUBAREA 1}

\section{Exposure of Previous Tidal Flat Composed of Cohesive Material}

Shoreline changes and the exposure of the previous tidal flat composed of cohesive material to waves were investigated. Figure 4 shows a satellite image of the subarea 1 between the Obitsu River and its north tributary, taken on March 29, 2012, and the station number (St.) in the field observation on April 19, 2014. The straight revetment along the right bank of the Obitsu River turns to the right at the river mouth, then extends northward, forming an L-shaped structure. A concave shoreline has formed north of this revetment, the shoreline gradually curves rightward with increasing distance from the river mouth and is connected to a sand spit formed on the left bank of the north tributary. The fomation of this sand spit at the north end clearly explains the predominance of northward longshore sand transport in this area.

Immediately north of the Obitsu River, there is an artificial mound from which a good view of the tidal flat is obtained. Figure 5 shows the view of the tidal flat and the L-shaped structure on the tidal flat, taken from St. 1 on the top of this mound. A revetment with a low crown height made of stones extends with a lagoon behind the revetment, whereas severe erosion has occurred at St. 2, forming a high scarp of $2 \mathrm{~m}$ height landward of the L-shaped revetment, and many trees have fallen over (Fig. 6). From this observation, it was assumed that the revetment was constructed to protect the land from erosion, and it was left behind because the area behind the revetment was eroded away. Figure 7 shows the receded concave shoreline at St. 3 immediately north of the L-shaped revetment. A wide tidal flat extends offshore of the shoreline, which is clearly separated from the foreshore by a line formed by a sharp break in the slope. Figure 8 shows a photograph of an exposed half-consolidated layer composed of cohesive material with many vegetation roots, taken at St. 4. Because a layer composed of cohesive

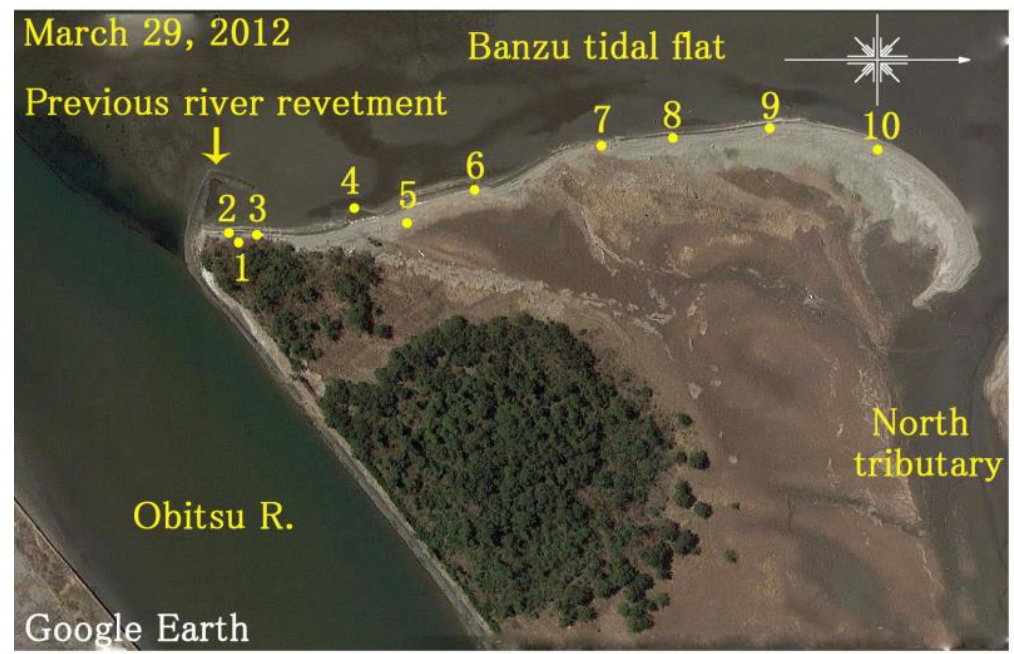

Figure 4. Satellite image of subarea 1 and locations of Sts. 1-10.

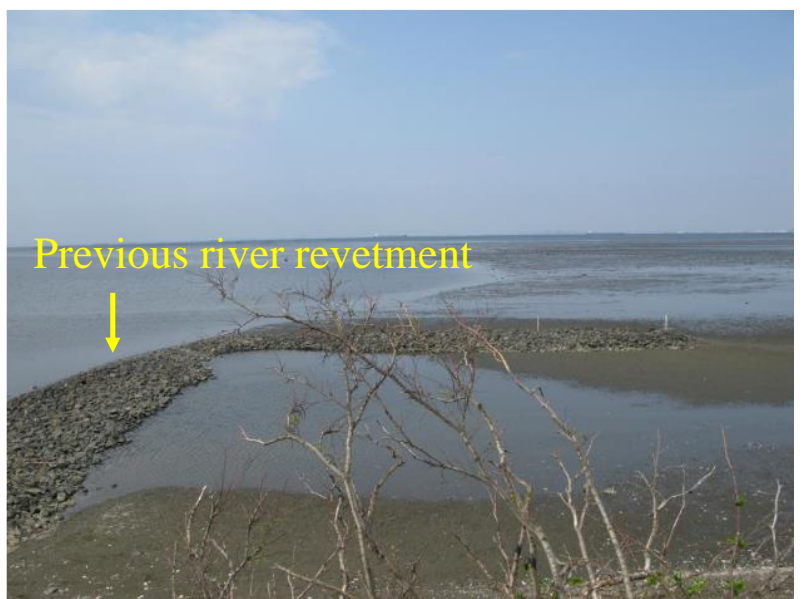

Figure 5. Photograph of L-shaped revetment, taken from the top of the mound immediately north of Obitsu River mouth. 
material is normally formed by the deposition of mud in a calm-wave zone, this exposure of the layer suggests that the area near St. 4 was located inside a lagoon behind a barrier island without intensive wave action in the past, and then the sand bar of the barrier island was eroded away, resulting in the exposure of the mud layer. The exposed layer is considered to have been maintained because the wellcompacted mud layer with many roots resisted wave abraision. The exposure of the mud layer with many vegetation roots implies that this area was once a wetland in the form of a lagoon with vegetation such as reeds, and the wetland was eroded with the recession of the shoreline.

A sand bar has developed with a lagoon behind it, and reeds are abundant at St. 5, as shown in Fig. 9. This is the evidence that this lagoon was enclosed behind the present sand bar by the successive

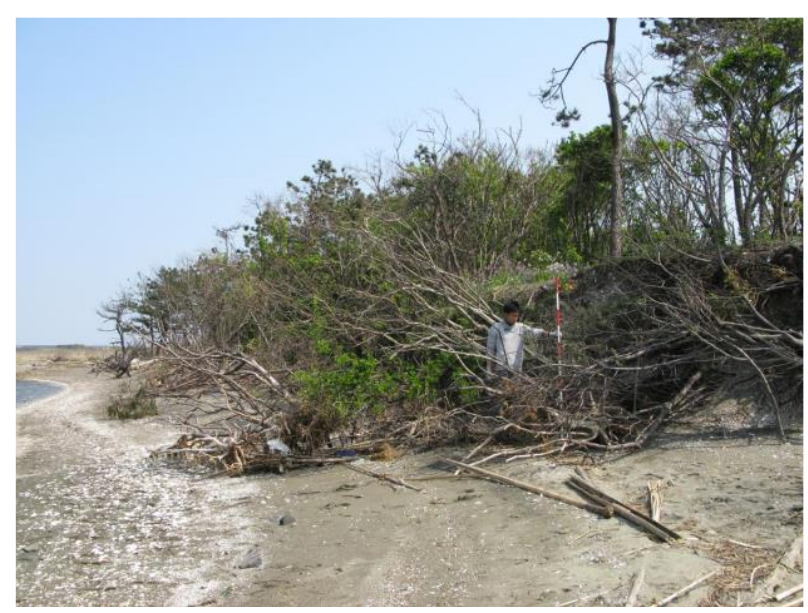

Figure 6. Scarp with $2 \mathrm{~m}$ height formed by erosion.

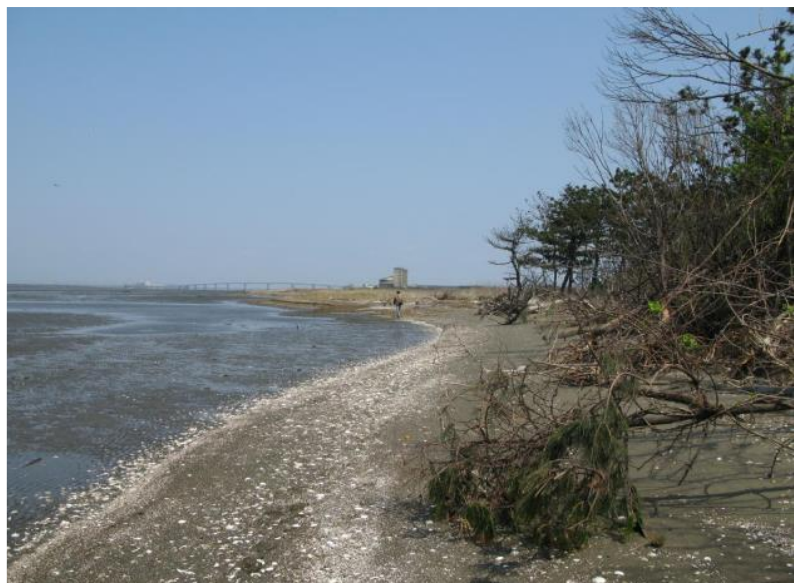

Figure 7. Concave shoreline extending from north end of L-shaped revetment.

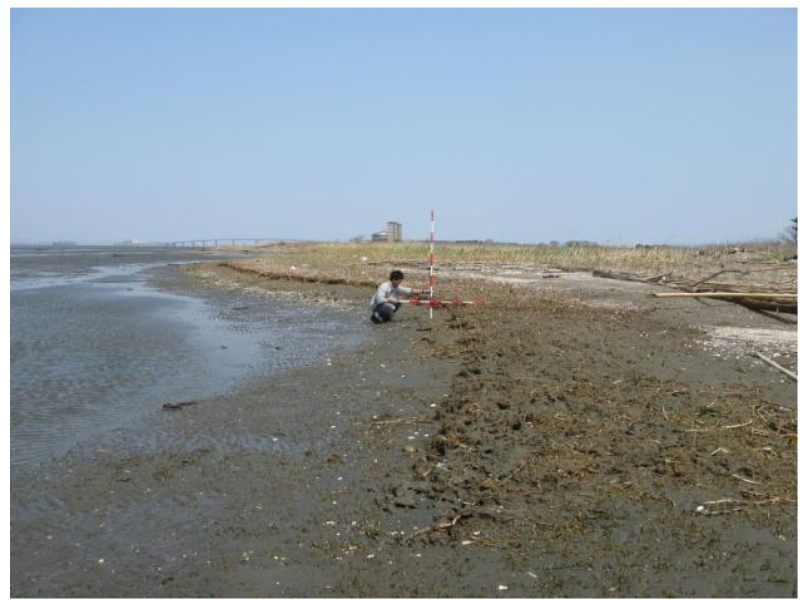

Figure 8. Photograph of exposure of tidal mud layer and roots of vegetation. 
recession of the shoreline around this area. Figure 10 shows the low-tide shoreline with a sharp break in the slope between the tidal flat with a gentle slope and a steep foreshore with a slope of 1/10 at St. 8 . This separation of the foreshore with a steep slope of $1 / 10$ and the offshore mud flat with a very gentle slope is one of the common characteristics observed on the marginal coasts of tidal flats, such as those in the Suo-nada Sea and elsewhere (San-nami et al. 2015). Furthermore, north of St. 8, the shoreline is significantly curved, as shown in Fig. 11, because of the development of a sand spit.

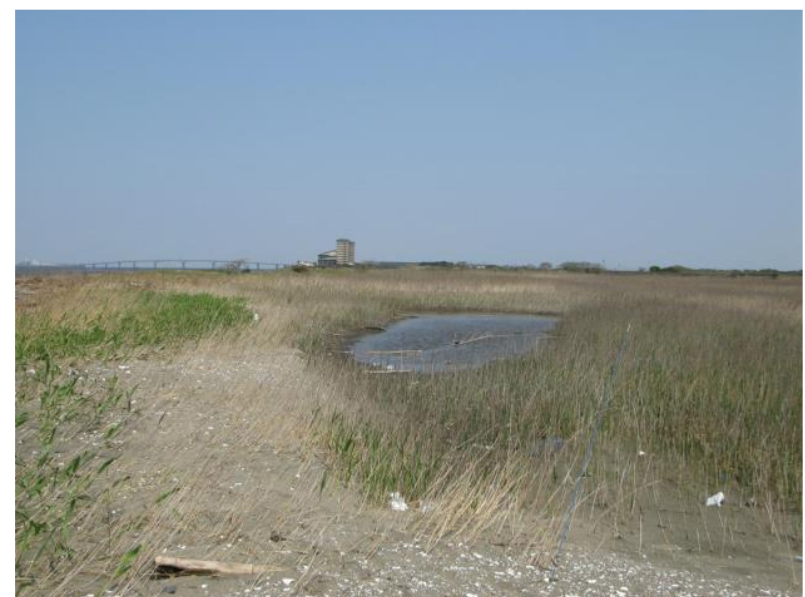

Figure 9. Lagoon behind barrier island covered with vegetation.

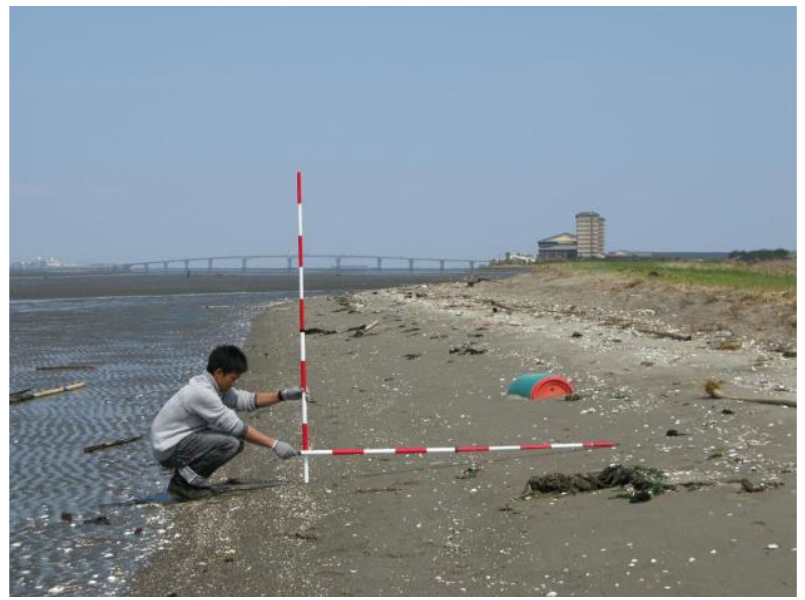

Figure 10 . Tidal flat and foreshore of $1 / 10$ slope clearly separated by the line formed by a sharp break in the slope.

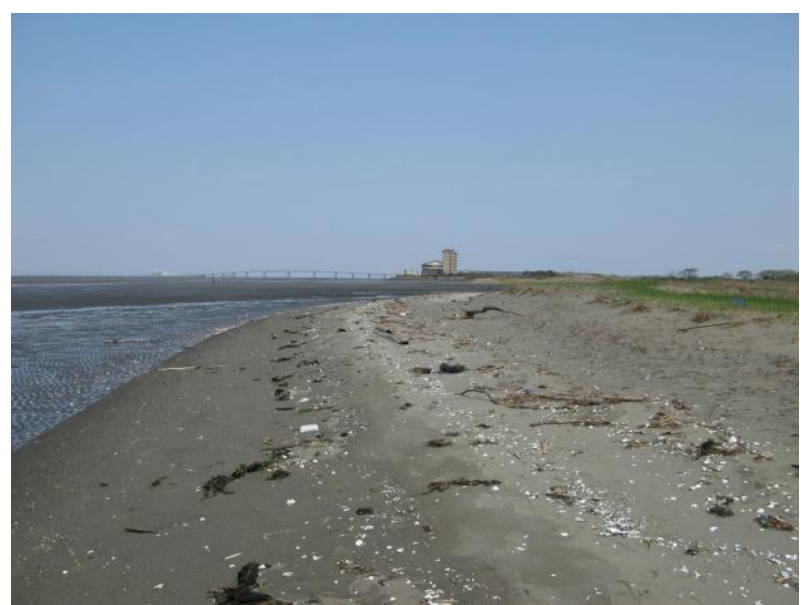

Figure 11. Convex profile formed by successive deposition of sand. 


\section{Shoreline Changes}

Figures 12-15 show aerial photographs taken in 1980, 1990, 2000, and 2010, respectively, together with the shoreline configurations in 2014 and 2016 and the location numbers of the site photographs taken on April 19, 2014. In 1980, the shoreline protruded significantly immediately north of the Obitsu River mouth, as shown in Fig. 12. At this time, Sts. 2 and 3 were located in a pine tree forest, whereas St. 4 with the exposed past mud layer was located close to a lagoon surrounded by a barrier island, and fine material was being deposited in the lagoon. Furthermore, Sts. 7-10 were located offshore of the shoreline in the tidal flat and were exposed to waves. By 1990, the sand bar located immediately north of the Obitsu River had moved northward and the curvature had increased (Fig. 13). At this time, the wetland area was narrowing because of the landward movement of the sand bar from the southwest side, but Sts. 4 and 5 were still located inside the lagoon. However, St. 6 was buried in the sand bar because of the further development of the sand bar. By 2000, the semicircular sand bar in 1990 had moved northward as a whole (Fig. 14). Beach erosion had intensified in front of St. 2 and the lagoon was buried by the sand bar near St. 4. Furthermore, Sts. 7 and 8, which were located in the tidal flat until

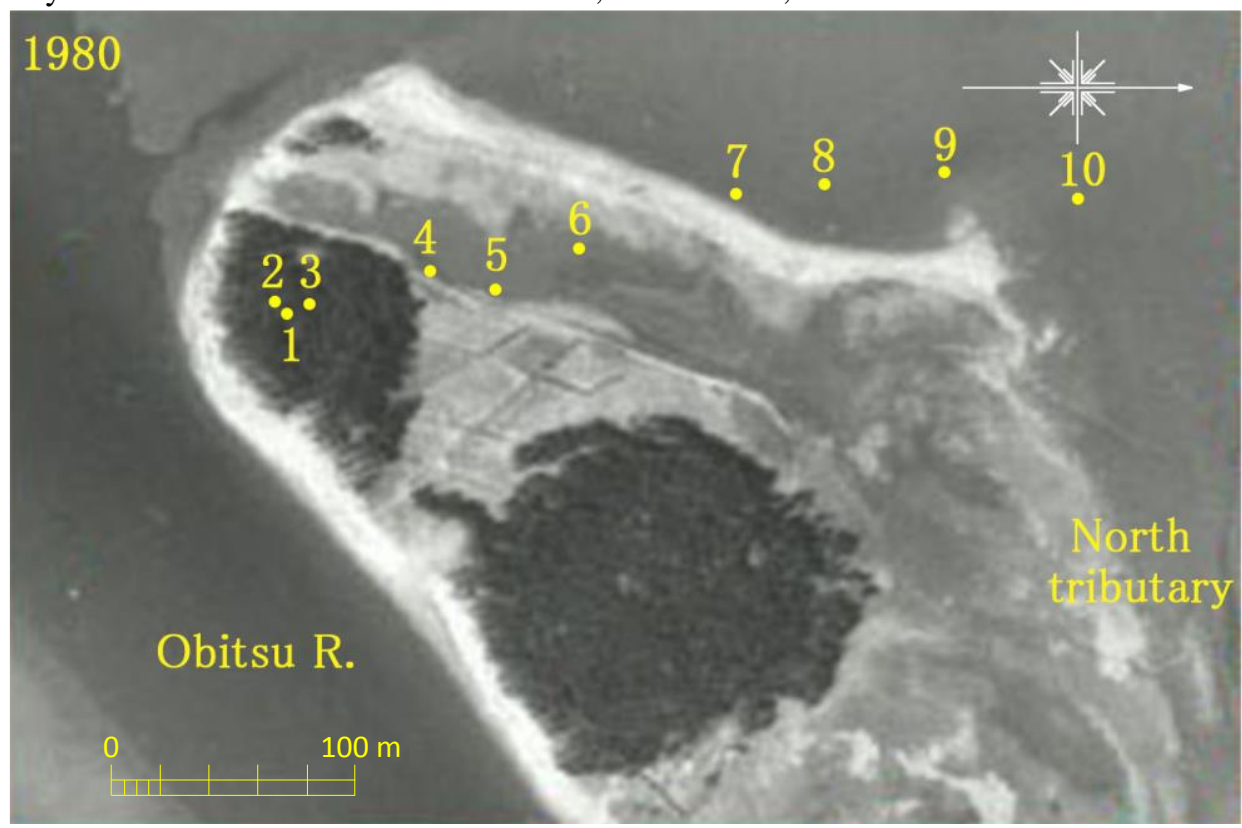

Figure 12. Aerial photograph taken in 1980 and locations of Sts. 1-10.

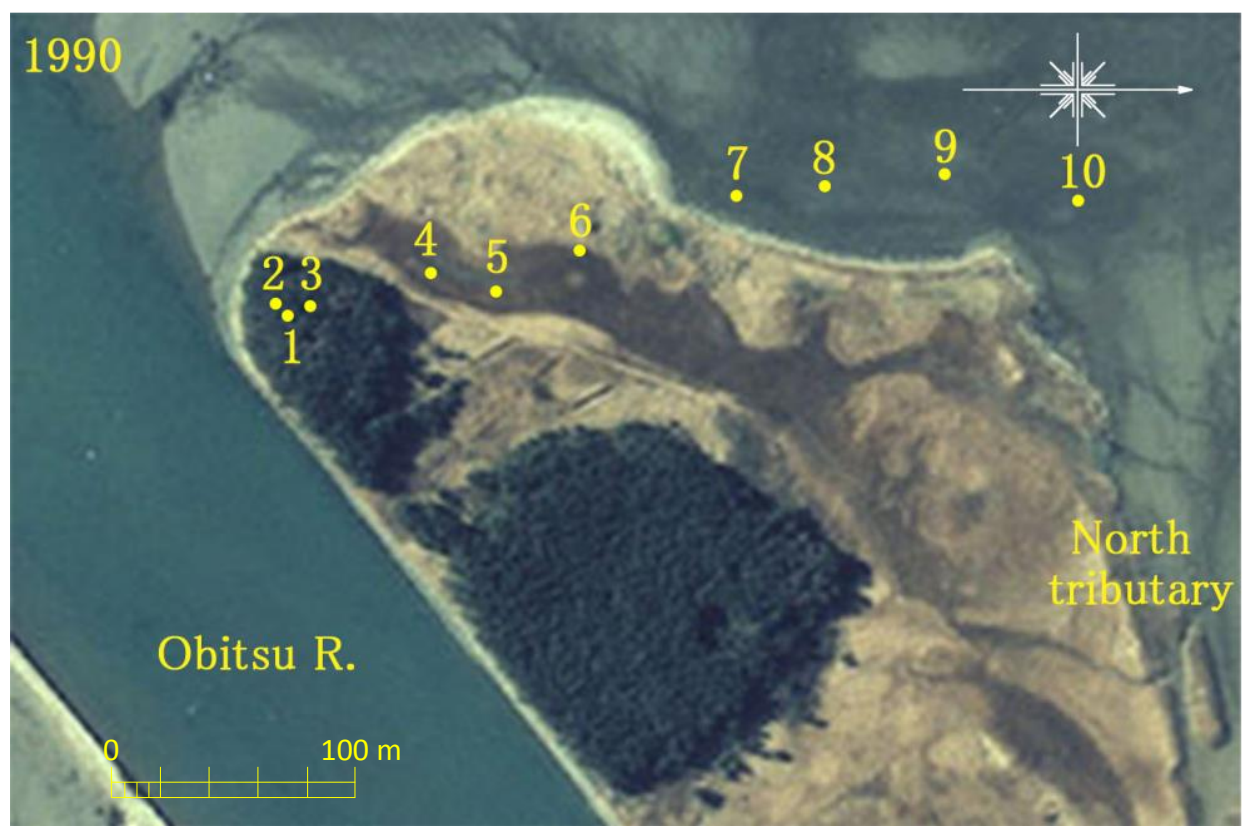

Figure 13. Aerial photograph taken in 1990 and locations of Sts. 1-10. 
1990, were now in the sand bar. By 2010, the protrusion that had formed offshore of Sts. 4-7 in 2000 had disappeared. Instead, sand was being deposited in the vicinity of St. 9, resulting in the extension of the sand spit near St. 10 (Fig. 15). The overall shape of the sand bar was similar to the present form.

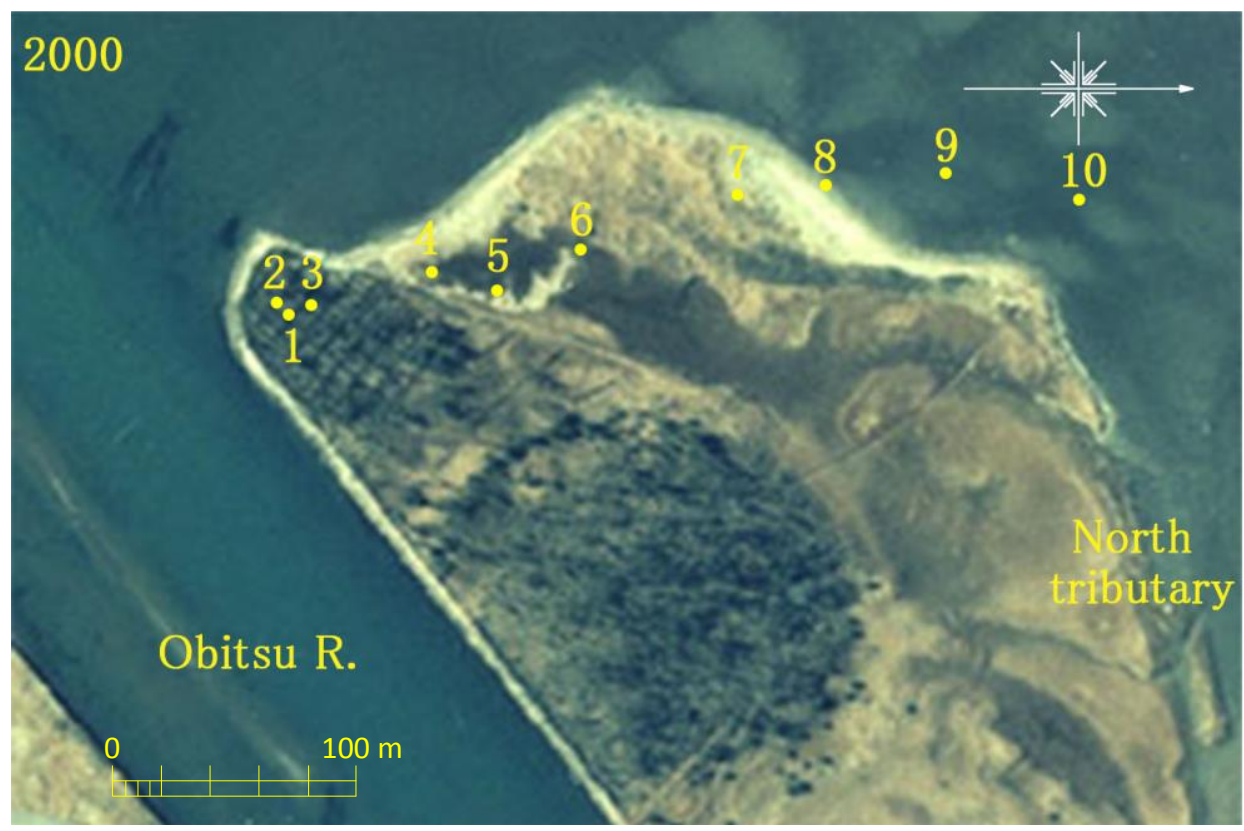

Figure 14. Aerial photograph taken in 2000 and locations of Sts. 1-10.

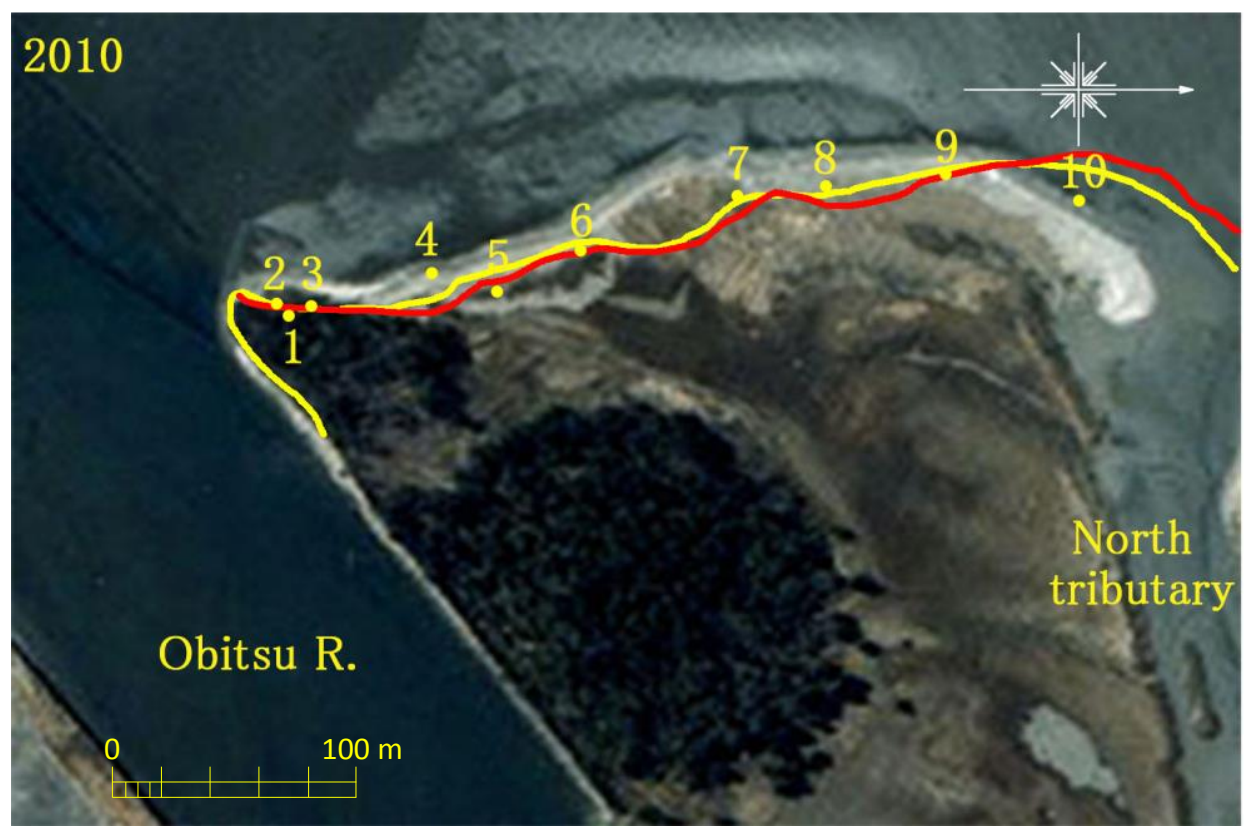

Figure 15. Aerial photograph taken in 2010 and locations of Sts. 1-10.

\section{BEACH CHANGES IN SUBAREA 2}

Figure 16 shows a satellite image of subarea 2 together with the shoreline in 2000 and the locations of the observation sites Sts. 11-16. A curved shoreline extends in this area, and a slender barrier encloses the salt marshes, as shown in the satellite image. First, at St. 11, north of the mouth of the tributary, many roots of the vegetation that have grown on the mud layer composed of cohesive material were truncated along the high-water shoreline, as shown in Fig. 17. In contrast, at St. 12, immediately landward of St. 11, a large amount of sand has been transported into the lagoon over the vegetation zone (Fig. 18). Since the disappearance of the sandy beach seaward of the vegetation zone is in marked contrast to the deposition of a large amount of sand immediately landward of the vegetation zone, it is 


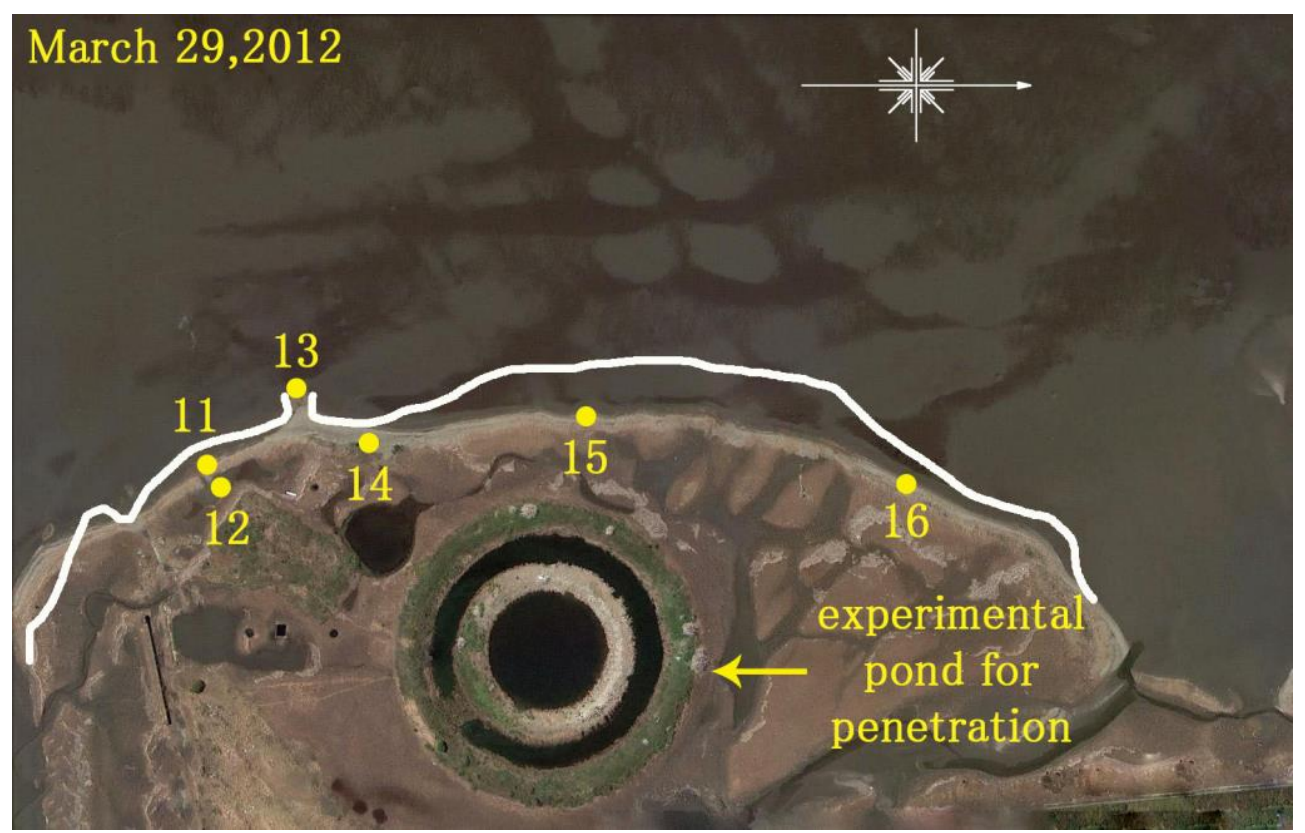

Figure 16. Satellite image of subarea 2 and locations of St. 11-16.

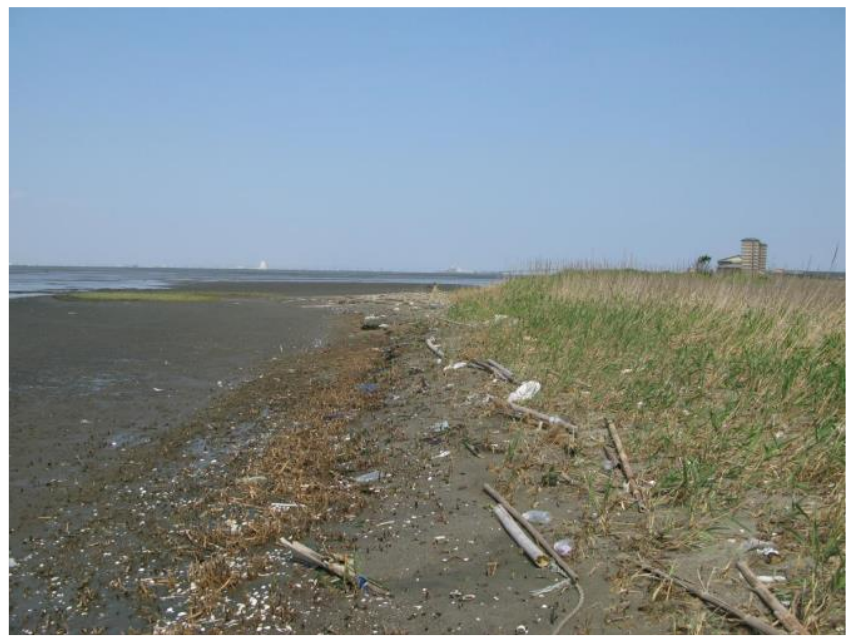

Figure 17. Many truncated roots of coastal vegetation grown on the mud layer composed of cohesive material along the high-water shoreline (St. 11).

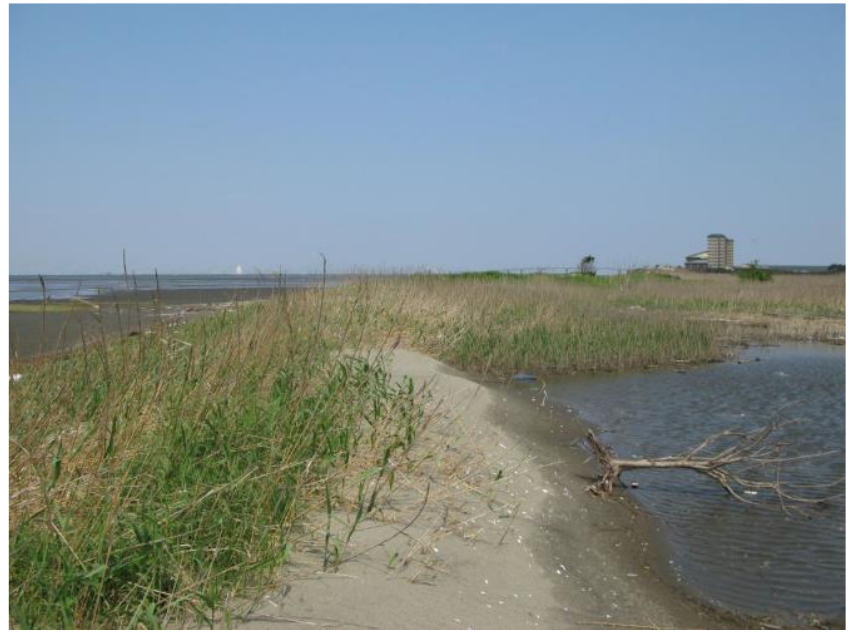

Figure 18. Deposition of sand behind vegetation zone caused by landward movement of sand (St. 12). 
concluded that a large amount of sand was transported landward in the cross-shore direction. Similarly, at St. $15,165 \mathrm{~m}$ north of the protruding vegetation zone, the beach was eroded and many vegetation roots were exposed, and a very gentle slope was left offshore of the vegetation zone (Fig. 19). Finally, at St. 16, sand had been transported landward and the reed field behind the previous sandy beach was buried by sand, implying the occurrence of landward sand movement across the sandy beach and vegetation area (Fig. 20).

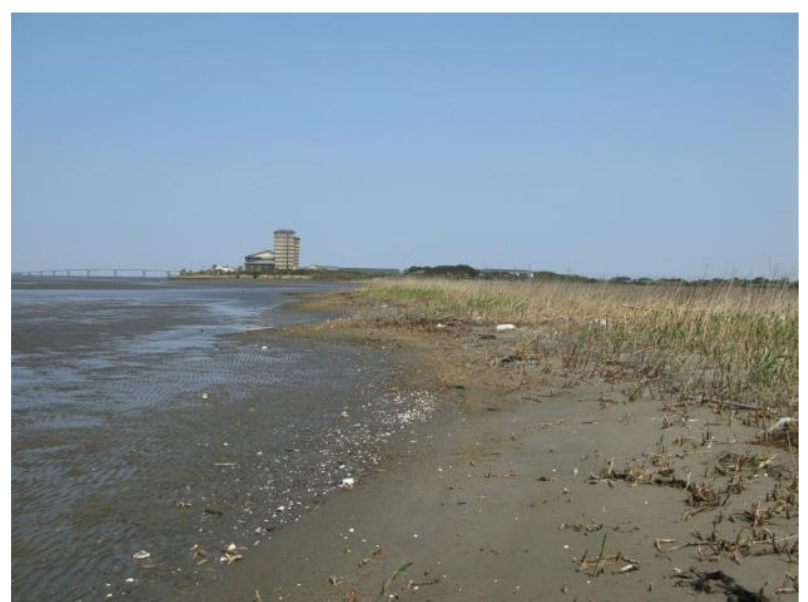

Figure 19. Eroded beach and exposure of many vegetation roots (St. 15).

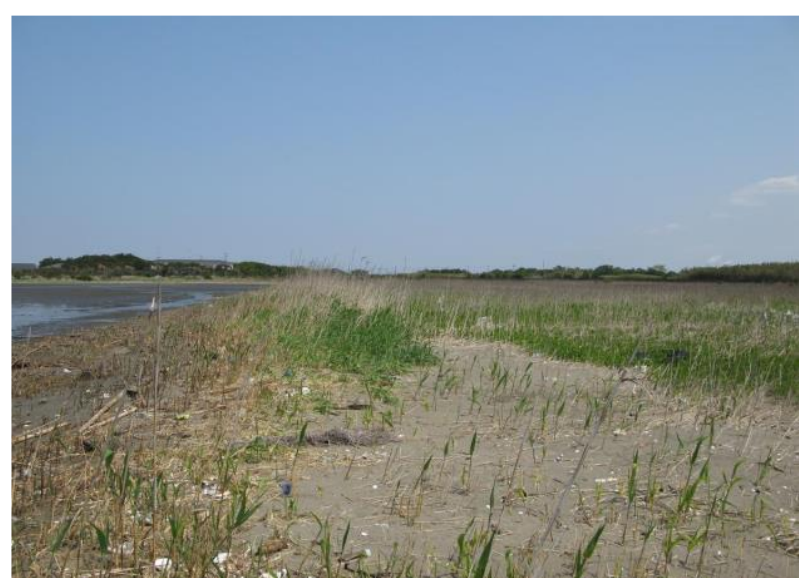

Figure 20. Deposition of sand inside vegetation zone (St. 16).

\section{LONG-TERM SHORELINE CHANGES IN SUBAREAS 1 AND 2}

The shoreline positions were determined from the aerial photographs, and the shoreline positions were corrected to match the MSL using a foreshore slope of $1 / 10$, which was determined by a beach survey and from the tide level. Figure 21 shows the shoreline changes between 1980 and 2010. Here, the shoreline changes since 1980 in the area north of point $\mathrm{P}$ were determined as the distances in the direction normal to the shoreline in 1980 . We examnined the changes along transects $\mathrm{A}, \mathrm{B}$, and $\mathrm{C}$ at $X=$ 100,180 , and $285 \mathrm{~m}$, respectively, as shown in Fig. 21. The shoreline at $X=100 \mathrm{~m}$ retreated by $65 \mathrm{~m}$ between 1980 and 2010. It was found that a scarp with $2 \mathrm{~m}$ height, as shown in Fig. 6, was formed near transect A because of the marked shoreline recession. Along transect B at $X=180 \mathrm{~m}$, although the shoreline advanced by $25 \mathrm{~m}$ between 1980 and 2000, it has been retreating since 2000, resulting in shoreline recession by $40 \mathrm{~m}$ in 2010 compared with that in 2000 . The erosion in the vicinity of transect $\mathrm{B}$ associated with the shoreline recession can be confirmed from the exposure of the cohesive mud layer with many truncated roots of reeds, as shown in Fig. 8. Although no large shoreline changes were observed along transect $\mathrm{C}$ at $X=280 \mathrm{~m}$ until 1990 , the shoreline has rapidly advanced since 2000 , and had advanced by $40 \mathrm{~m}$ by 2010 compared with the shoreline in 1990. Because of the formation of a sand spit at the north end, a curved shoreline with an upward convex profile was formed, as shown in Fig. 11. As shown by these photographs, the shoreline changes in subarea 1 were found to be mainly 
triggered by northward longshore sand transport. In contrast, the entire shoreline has receded since 1980 in subarea 2.

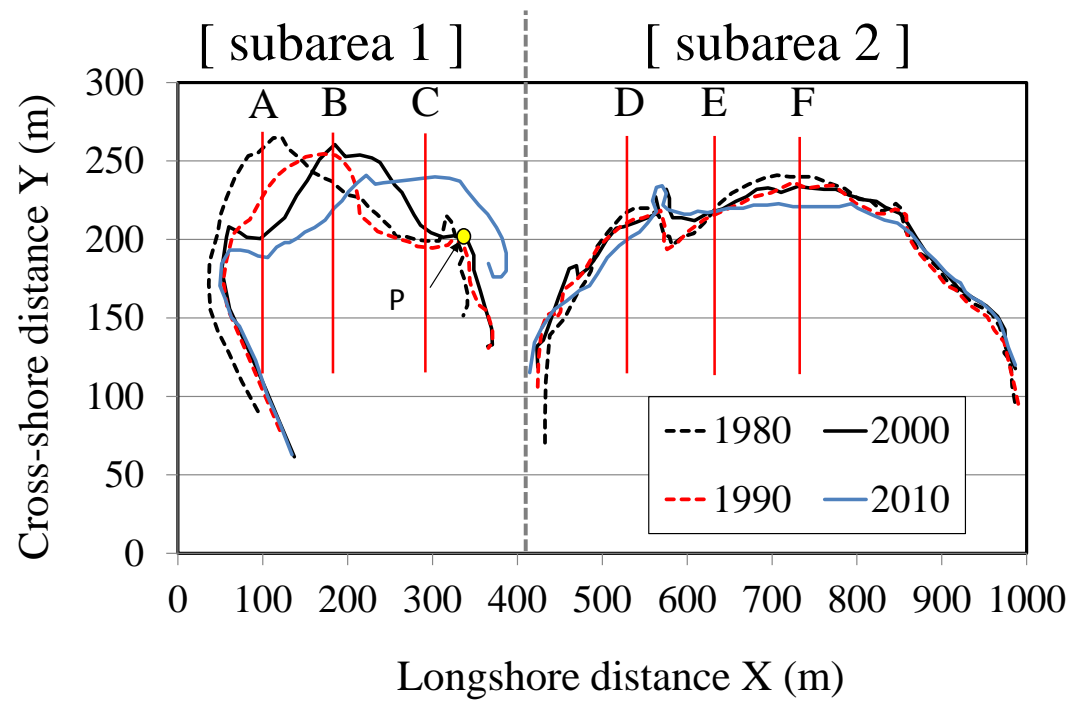

Figure 21. Long-term shoreline changes between 1980 and 2010.

\section{ESTIMATION OF LONGSHORE SAND TRANSPORT}

\section{Longitudinal Profile and Thickness of Sand Layer}

Figure 22 shows the beach profiles measured along transects $\mathbf{a}-\mathbf{f}$, as shown in Fig. 2, together with the boundary between the sand and mud layers. Along transects $\mathbf{a}$ and $\mathbf{b}$, a triangular sand bar (barrier) was formed with berm heights of 1.18 and $1.9 \mathrm{~m}$, respectively. In contrast, the berm height decreased to $1.04 \mathrm{~m}$ along transect $\mathbf{c}$, while the width of the sand bar increased to $47 \mathrm{~m}$ with two berm peaks. The elevation of the boundary between the sand and mud layers was $Z=0.5 \mathrm{~m}$ along transects $\mathbf{a}$ and $\mathbf{b}$, and $Z=0.4-0.6 \mathrm{~m}$ along transect $\mathbf{c}$; both are in good agreement with the HWL of $+0.5 \mathrm{~m}$ above MSL. Similarly, the elevation of the boundary between the sand and mud layers was $Z=0.4-0.6 \mathrm{~m}$ along transects $\mathbf{d}$, e, and $\mathbf{f}$ north of the tributary. The maximum thicknesses of the sand layers were 0.6 (transect a), $1.3(\mathbf{b}), 0.7(\mathbf{c}), 0.6(\mathbf{d}), 0.7(\mathbf{e})$, and $0.9 \mathrm{~m}(\mathbf{f})$.

Because the sand composing the barrier was deposited on the cohesive mud layer, the change in the cross-sectional area of the barrier $(\Delta A)$ was calculated, and the relationship between $\Delta A$ and the width of the sand layer was investigated. The regression coefficient is equal to the characteristic height of beach changes, which can be used as a coefficient to transform the shoreline changes into the changes in the cross-sectional area of the beach. In this case, it was found to be $0.37 \mathrm{~m}$.

\section{Estimation of Longshore Sand Transport}

The shoreline changes between 2000 and 2014 were calculated with reference to the shoreline in 1990, and the change in the foreshore area was calculated by integrating the shoreline change alongshore, selecting the upstream end of the sand spit $(X=370 \mathrm{~m})$ at the mouth of the tributary as the reference point and $X=1,000 \mathrm{~m}$ at the north end of the study area, where longshore sand transport is assumed to be 0 . Then, by transforming the change in the foreshore area into the change in volume by multiplying it by the characteristic height of the beach changes $(0.37 \mathrm{~m})$, and dividing by the elapsed time, the distribution of longshore sand transport was calculated (Fig. 23). The distribution of longshore sand transport in the south area corresponds well to the beach changes, where the beach is eroded immediately north of the Obitsu River, whereas a sand spit elongates at the mouth of the tributary. The location of maximum sand transport gradually moved northward from $X=175 \mathrm{~m}$ in 2000 to $X=230 \mathrm{~m}$ in 2014, and the maximum amount was reduced over time from $Q=127 \mathrm{~m}^{3} / \mathrm{yr}$ in 2000 to $74 \mathrm{~m}^{3} / \mathrm{yr}$ in 2014.

In the area north of the tributary, northward longshore sand transport prevailed in 2000, but it had decreased to a negligible amount by 2010, and thereafter, southward longshore sand transport appeared to be taking place in 2014. Since an artificial mound was left at $X=570 \mathrm{~m}$ north of the tributary, which 
locally prevented longshore sand transport by waves incident from the southwest, a slight change in longshore sand transport can be observed. In conclusion, it appears that the direction of longshore sand transport reversed over time, which cannot be observed under ordinary conditions, north of the tributary.

transect a

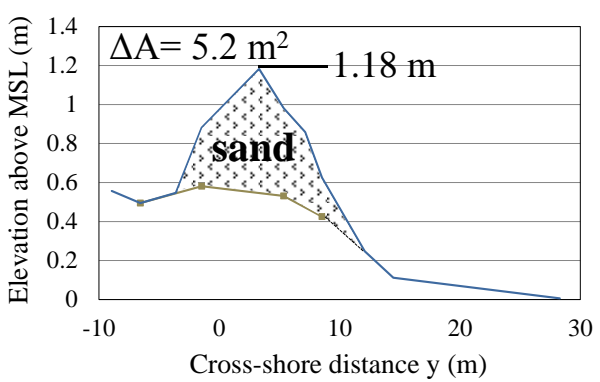

transect $b$

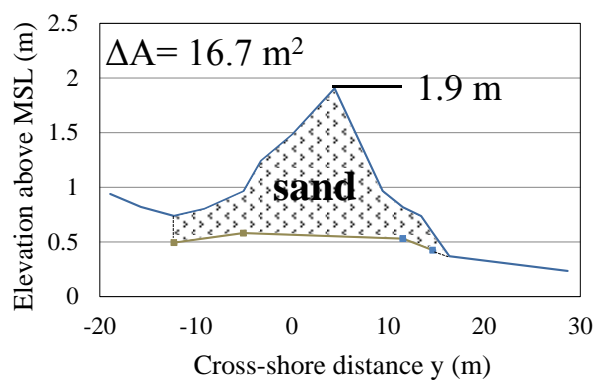

transect c

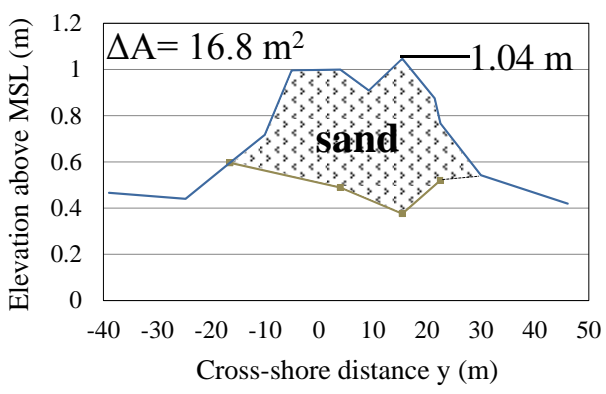

transect d

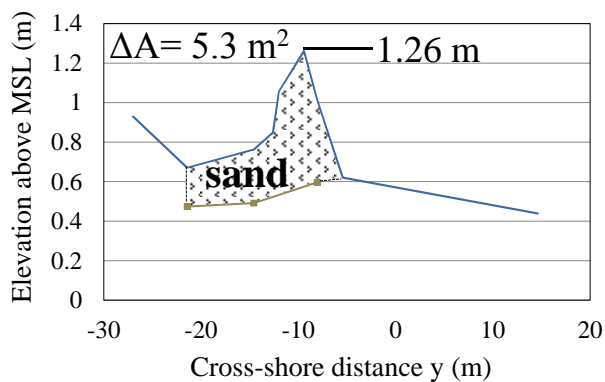

transect e

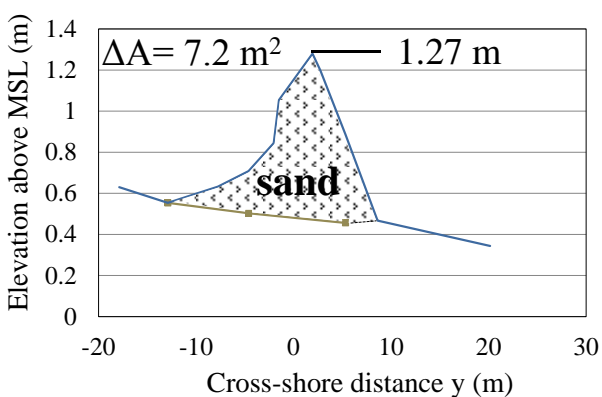

transect $\mathrm{f}$

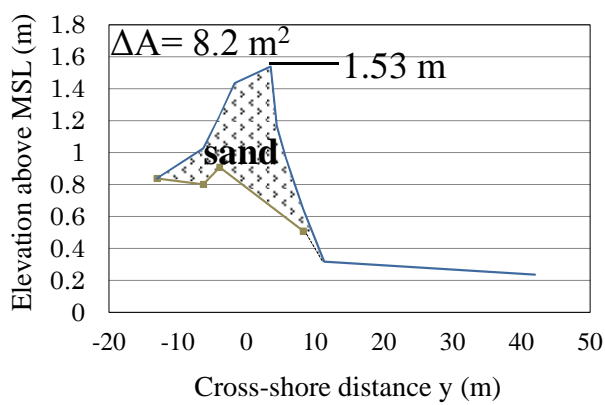

Cross-shore distance y $(\mathrm{m})$

Figure 22. Cross sections of beach ridges along six transects.

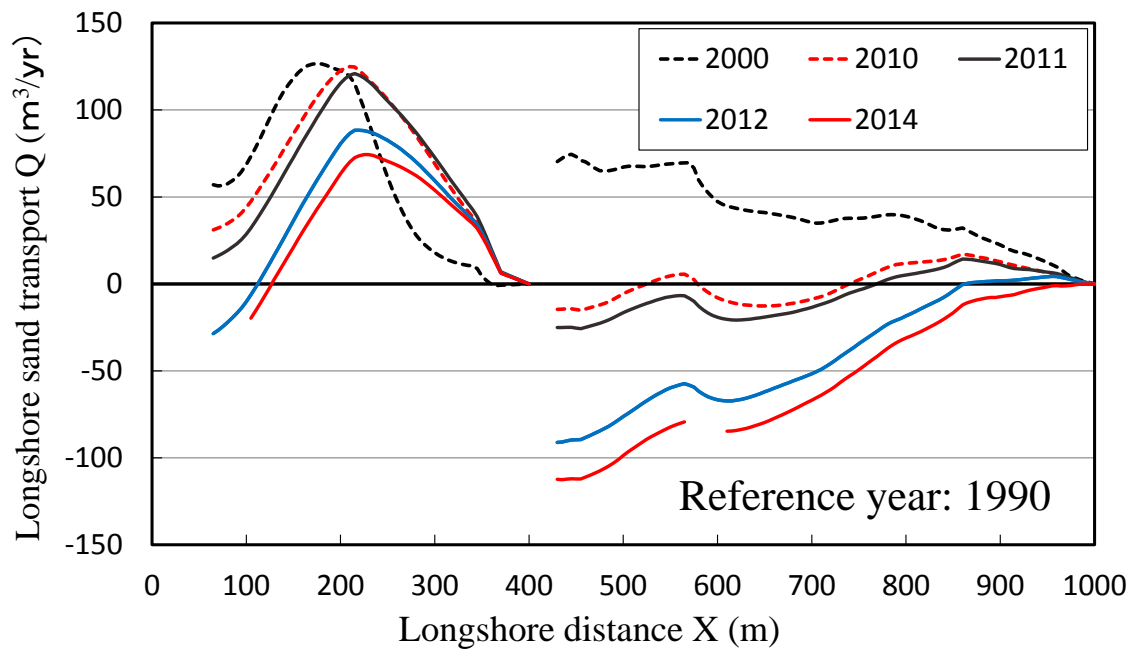

Figure 23. Distribution of longshore sand transport. 


\section{RAPID SHORELINE RECESSION OWING TO TSUNAMI OVERFLOW}

During the 2011 Great Earthquake on March 11, 2011, the resulting tsunami propagated deep into Tokyo Bay. At Futtsu point, a tsunami run-up height of approximately $2 \mathrm{~m}$ was measured (Mita et al. 2014). Also, a 1.3-m-high tsunami was measured at Harumi (Japan Meteorological Agency 2011), as shown in Fig. 1. Thus, a tsunami of a similar magnitude inundated the Banzu tidal flat and was assumed to cause topographic changes. Therefore, this situation was investigated using aerial photographs taken before and after the tsunami. Figure 24 shows aerial photographs taken on January 30, 2011 and March 27, 2012. In each photograph, the seaward and landward boundaries of the beach ridge extending along the shoreline are denoted by red and blue lines, respectively. Also, the maximum inundation line, which can be identified by the deposition of debris, is shown by a thick broken line in Fig. 24(b). Debris was carried landward over the lowland by the tsunami.

\section{(a) January 30, 2011}

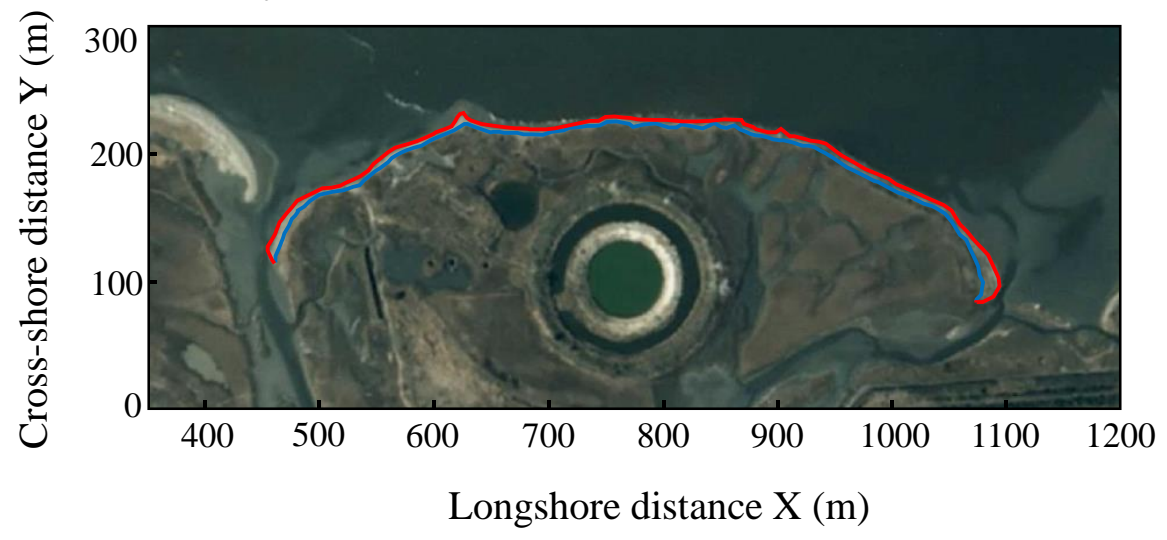

(b) March 27, 2012

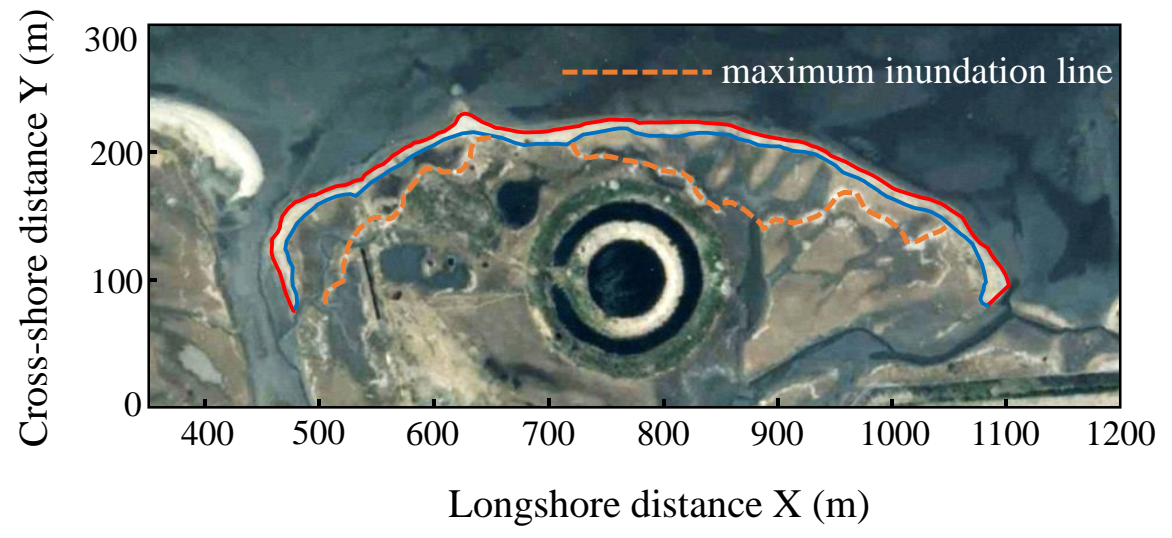

Figure 24. Aerial photographs taken before and after tsunami.

Figure 25 shows the seaward and landward boundaries of the sand bars on January 30, 2011 and March 27, 2012, respectively, and the shoreline changes in subareas 1 and 2 with reference to 1980. It was found that in subarea 2 the sand bars had moved landward by $7 \mathrm{~m}$ on average parallel to the shoreline, together with a $27 \mathrm{~m}$ extension of the southern tip of the sand bar. In this case, the peripheral length of the sand bars was almost constant: $2008 \mathrm{~m}$ in 2011 and $2049 \mathrm{~m}$ in 2012. Moreover, the planar areas of the sand bars were $1.25 \times 10^{4} \mathrm{~m}^{2}$ in 2011 and $1.08 \times 10^{4} \mathrm{~m}^{2}$ in 2012 . This means that the sand bars moved landward while maintaining an almost constant volume of sand, that is, the cross section of the sand bar moved in the same direction. Sand was only deposited on the mud layer composed of cohesive material and formed a small hump, as shown in Fig. 20. The parallel movement of the shoreline occurred with the landward movement of the sand bars. In Fig. 17, the roots of the vegetation were truncated, whereas in Fig. 18 immediately landward of the site, a large amount of sand was deposited on the lagoon over the vegetation zone. The disappearance of the sandy beach seaward of the vegetation zone can be successfully explained by this landward transport of sand by the tsunami. 
Because of this parallel movement of the shoreline, an apparent change in the foreshore area occurred, resulting in a decrease in the sand volume, and the distribution of longshore sand transport shown in Fig. 23 was obtained in the area north of the tributary. Although in subarea 1 sand movement similar to that in subarea 2 occurred owing to the tsunami, as shown in Fig. 23, large longshore sand transport masked the shoreline changes.

(a) Configuration of shoreline and beach ridge

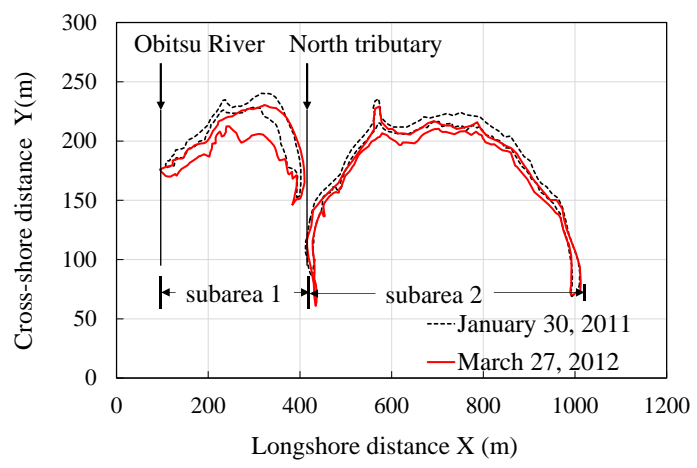

(b) Shoreline change

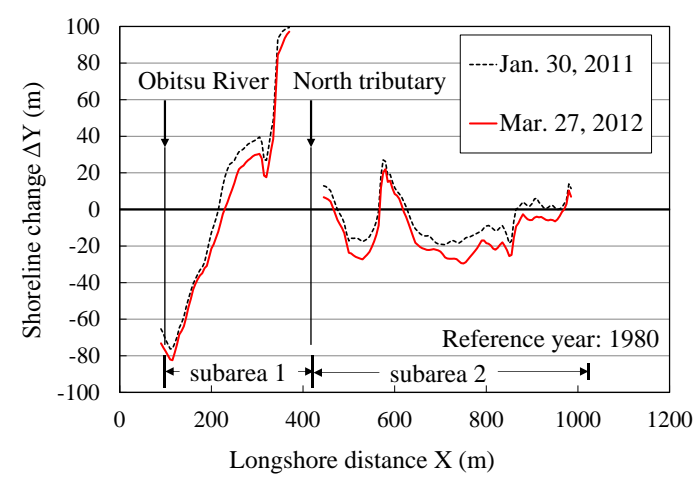

Figure 25. Changes in configuration of shoreline and beach ridge.

\section{CONCLUSIONS}

Long-term topographic changes on the marginal coasts of the Banzu tidal flat in Tokyo Bay were investigated. The area immediately north of the mouth of the Obitsu River was eroded owing to the decrease in sand supply from the Obitsu River, resulting in the exposure of a layer composed of cohesive material in the previous tidal flat, and sand was transported to the mouth of the north tributary and formed a sand spit there. In this case, the maximum longshore sand transport rate was estimated to be $127 \mathrm{~m}^{3} / \mathrm{yr}$, three orders of magnitude smaller than that on exposed beaches, because the site is located in Tokyo Bay. In 2011, a tsunami propagated deep into Tokyo Bay, and the marginal coasts of the tidal flat were severely affected by this tsunami, causing the inundation of beach ridges and their deformation. The impact of this tsunami was also investigated, and parallel movements of sand bars due to the tsunami overflow were observed. It was concluded that the tsunami had a considerable impact on the topography around the marginal coasts of the Banzu tidal flat.

\section{REFERENCES}

Japan Meteorological Agency. 2011. http://www.jma.go.jp/jma/kishou/books/saigaiji/saigaiji_20 1101/saigaiji_201101.html.

Mita, K., A. Kobayashi, T. Uda, and Y. Noshi. 2014. Beach changes along northern coast of Futtsu cuspate foreland and effect of 2011 Great Tsunami, Proc. JSCE, B3 (Civil Eng. in the Ocean), 70 (2), I_600-I_605, 2014. (in Japanese)

Murakami, K. 2008. Characteristics comparison of different type tidal flats in Tokyo Inner Bay using water environment soundness index, Proc. JSCE, B3 (Civil Eng. in the Ocean), 67(2), I_469I_474, 2011. (in Japanese)

San-nami, T., T. Uda, S. Miyahara, and M. Serizawa. 2015. Deformation of an isolated offshore sand bar on tidal flat and mergence with beach due to waves, Coastal Sediments '15, CD-ROM, 14, pp. $1-14$. 